\title{
The Right to Property in the ECHR Case Laws: Cases against Albania
}

\author{
Alban Alimema \\ PHD candidate, Attorney \\ University of Tirana, Faculty of Law; Kola \& Associates Law Firm \\ E-mail: a.alimema@kola-associates.com
}

\section{Doi:10.5901/mjss.2014.v5n7p85}

\begin{abstract}
Issues to be addressed in this paper refer to some aspects of the right to property in relation to Article 1 of Protocol 1 of the European Convention on Human Rights analyzed by the ECHR in the cases against Albania. More specifically, this paper refers to issues related to the right of ownership such as the deprivation of property rights through expropriation, interventions that lead to restriction of the right of ownership, the concept of ownership etc. For the purpose of this paper will be to analyze a series of cases decided by the ECHR, such as Beshiri etc. v. Albania; Gjonbocari etc v. Albania; Nikolaus and Jurgen Treska v. Albania; Marini v. Albania; Ramadhi v. Albania etc.
\end{abstract}

Keywords: right to property; peaceful enjoyment of property; deprivation of possessions; existing assets; legitimate expectations;

\section{Introduction}

One of the most controversial and complex human rights is the right to property. The right is controversial because the very right which is seen by some as central to the human rights concept is considered by others to be an instrument for abuse. One might say that it is a right that protects the 'haves' against the 'have-nots'. It is complex, because no other human right is subject to more qualifications and limitations and, consequently, no other right has resulted in more complex case-law of, for instance, the supervisory bodies of the ECHR. It is complex also because it is generally regarded as a civil right, even an integrity right; a right which obliges the state to abstain from interfering. At the same time, it clearly displays characteristics of a social right with significant implications for the distribution of social goods and wealth. Moreover, the right to property has major implications for several important social and economic rights such as the right to work, the right to enjoy the benefits of scientific progress, the right to education and the right to housing.

Property has been defined in the case-law of the European Courts of Human Rights as 'any vested right' or 'any object capable of having value'. As such the concept of property has an autonomous meaning, often substantially different from national legislation. It may also include rights which result from rent or lease agreements and - under certain conditions - benefits from public relationships, such as public pension schemes. Extensive case-law has been established to protect individuals against abuse of property. The right to property as found in European Convention on Human Rights, however, does not include the right to acquire property.

Issues to be addressed in this paper refer to some aspects of the right to property in relation to Article 1 of Protocol 1 of the European Convention on Human Rights analyzed by the ECHR in the cases against Albania. More specifically, this paper refers to issues related to the right of ownership such as the deprivation of property rights through expropriation, interventions that lead to restriction of the right of ownership, the concept of ownership etc. For the purpose of this paper will be analyzed a series of cases decided by the ECHR, such as Beshiri etc. v. Albania; Gjonbocari etc v. Albania; Nikolaus and Jurgen Treska v. Albania; Marini v. Albania; Ramadhi v. Albania etc.

\section{Various Aspects Related to the Interpretation of Property Rights under Article 1 Protocol No. 1 of the European Convention}

Article 1 Protocol No. 1 of the European Convention provides that:

"Every natural or legal person is entitled to the peaceful enjoyment of his possessions. No one shall be deprived of his possessions except in the public interest and subject to the conditions provided for by law and by the general principles of international law.

The preceding provisions shall not, however, in any way impair the right of a State to enforce such laws as it deems 
necessary to control the use of property in accordance with the general interest or to secure the payment of taxes or other contributions or penalties".

From the very beginning, a broad interpretation has been given to the meaning of property by the ECHR ${ }^{1}$. This broad interpretation has evolved gradually.

In the most of the cases against Albania, the Europian Court reiterated its position on the right to property (under Article 1 of Protocol No. 1) stating that the Court has consistently interpreted the right to property as comprising three distinct rules. This interpretation is useful in gaining a general understanding of the various elements of property. The first rule is of a general nature and lays down the principle of peaceful enjoyment of property. The second rule covers deprivation of possessions and subjects it to certain conditions. The third recognizes that the states are entitled under the European Convention, amongst other things, to control the use of property in accordance with the general interest. The second and third rules, which are concerned with particular instances of interference with the right to peaceful enjoyment of property, should be interpreted in light of the general principle laid down in the first rule.

This interpretation given by the European Court is useful to have a general understanding of the various elements of the right to property.

\section{Relevant Principles of the Right to property Established by the Case-Law of ECHR.}

In some of the cases against Albania the Court has reiterated the following principles established in its case-law under Article 1 of Protocol No. 1:

(a) Deprivation of ownership or of another right in rem is in principle an instantaneous act and does not produce a continuing situation of "deprivation of a right"2;

(b) Article 1 of Protocol No. 1 does not guarantee the right to acquire property3;

(c) An applicant can allege a violation of Article 1 of Protocol No. 1 only in so far as the impugned decisions related to his "possessions" within the meaning of this provision. "Possessions" can be either "existing possessions" or assets, including claims, in respect of which the applicant can argue that he or she has at least a "legitimate expectation" of obtaining effective enjoyment of a property right. By way of contrast, the hope of recognition of a property right which it has been impossible to exercise effectively cannot be considered a "possession" within the meaning of Article 1 of Protocol No. 1, nor can a conditional claim which lapses as a result of the non-fulfillment of the condition ${ }^{4}$;

(d) Where the proprietary interest is in the nature of a claim it may be regarded as an "asset" only where it has a sufficient basis in national law, for example where there is settled case-law of the domestic courts confirming it or whether it takes the form of a final enforceable judgment in an applicant's favor ${ }^{5}$;

(e) Article 1 of Protocol No. 1 cannot be interpreted as imposing any general obligation on the Contracting States to return property which was transferred to them before they ratified the Convention. Nor does Article 1 of Protocol No. 1 impose any restrictions on the Contracting States' freedom to determine the scope of property restitution and to choose the conditions under which they agree to restore property rights of former owners ${ }^{6}$;

\section{Meaning of Possessions: "Existing Possessions" and "Legitimate Expectation"}

In all the cases against Albania (in which is involved an alleged violation of article 1 of protocol no. 1 to the convention) the Court reiterated its position that the "Possessions" can be either "existing possessions" or assets, including claims, in respect of which the applicant can argue that he or she has at least a "legitimate expectation" of obtaining effective enjoyment of a property right. By way of contrast, the hope of recognition of a property right which it has been impossible to exercise effectively cannot be considered a "possession" within the meaning of Article 1 of Protocol No. 1, nor can a conditional claim which lapses as a result of the non-fulfillment of the condition.

In a general sense the Court has set forth that "property" shall mean "existing assets" or any "legitimate

${ }_{1}$ Prof.As.Dr. Ardian Nuni, LL.M Nada Dollani (2006). The right to property under the Europian Convention on Human Rights. Legal Studies Journal No 1. Tirana.

2 Judgment of ECHR, November 13, 2007. Aplication No. 38222/02, Ramadhi and Others v. Albania.

3 Judgment of ECHR, August 22, 2006. Aplication No. 7352/03, Beshiri and Others v. Albania.

${ }_{4}^{4}$ Judgment of ECHR, March 24, 2009. Aplication No. 2141/03, Vrioni and Others v. Albania.

5 Judgment of ECHR, December 18, 2007. Aplication No. 3738/02, Marini v. Albania.

6 Judgment of ECHR, November 13, 2007. Aplication No. 33771/02, Driza v. Albania. 
expectation" to win the right to property.

\title{
4.1 Existing possessions
}

In its case-law the Court has reiterated that the concept of "possessions" in Article 1 of Protocol No. 1 has an autonomous meaning and certain rights and interests constituting assets can also be regarded as "property rights", and thus as "possessions" for the purposes of this provision. It includes not only the traditional right to property over the items, but also other real rights (including the benefits from a contract or annual lease), intellectual property, personal rights, monetary claims against public authorities (claims for compensation ), claims for pensions and social assistance benefits, claims for licenses to bring property rights etc ${ }^{7}$.

In the case Marini v. Albania the Court has found that the shares held in a company constituted "possessions" within the meaning of Article 1 of Protocol No. 1. More specifically, the Court has held that since the applicant (Marini) claimed that after the prolonged failure of its partner, the State, to meet its obligations arising with the creation of the joint venture "Marin-Albplastik", and changes in activity factory production as a result of the contracts between the state and other parties, part of his stock in the company is reduced in value and therefore he had lost control over the activities and assets of the company. The Court found that the shares held by the applicant undoubtedly had an economic value and constituted "possessions" within the meaning of Article 1 of Protocol No. 1. . It observes in that connection that a "company share" is a complex thing. It certifies that the holder possesses a share in the company together with corresponding rights. That is not only an indirect claim on company assets, but other rights, especially voting rights and the right to influence the company, may stem from the share ${ }^{8}$.

\subsection{Legitimate expectation}

As mendtioned above, the Court has held that "property" shall be considered even any assets, including claims, in respect of which the applicant can argue that he or she has at least a "legitimate expectation" of obtaining effective enjoyment of a property right.

In Driza v. Albania, the Court reiterated its position that in order for a claim to be capable of being considered an "asset" falling within the scope of Article 1 of Protocol No. 1, the claimant must establish that it has a sufficient basis in national law, for example where there is settled case-law of the domestic courts confirming it or where there is a final court judgment in the claimant's favor. Where that has been done, the concept of "legitimate expectation" can come into play9.

Further, in Ramadhi and others v. Albania, the Court has held that:

\begin{abstract}
"Since the Court has declared inadmissible the last three applicants' complaint as regards the non-enforcement of the judgment of 4 February 2000, these applicants have had no "legitimate expectation", based either on the provisions of the Land Act or on the decisions given in relation to their claim for restitution of the plot of land measuring 30,500 sq. m. [...] since the applicants' relevant property had been nationalized, pursuant to the Property Acts and the Land Act in conjunction with the decisions given in their favor, they had a claim to compensation in value and kind which was clearly established in domestic law [... [In these circumstances, the Court considers the applicants' claim sufficiently established to qualify as an "asset" for the purposes of Article 1 of Protocol No. 1."10
\end{abstract}

While in the case Gjonboçari and Others v. Albania, the Court has held that:

"In the light of its case-law, the Court does not contemplate the existence of a "genuine dispute" or an "arguable claim" as a criterion for determining whether there is a "legitimate expectation" protected by Article 1 of Protocol No. 1. The Court takes the view that, where the proprietary interest is in the nature of a claim, it may be regarded as an "asset" only where it has a sufficient basis in national law, for example where there is settled case-law of the domestic courts confirming it. In particular, the Court notes that the domestic courts which decided the case in the final instance found that the applicants' claim for restitution of their parents' property depended on the issuance of a new document which complied with formal requirements. The judgment delivered by the Supreme Court did not invest the applicants with an

\footnotetext{
${ }^{7}$ Prof.As.Dr. Ardian Nuni, LL.M Nada Dollani (2006). The right to property under the Europian Convention on Human Rights. Legal Studies Journal No 1. Tirana.

8 Judgment of ECHR, December 18, 2007. Application No. 3738/02, Marini v. Albania.

9 Judgment of ECHR, November 13, 2007. Application No. 33771/02, Driza v. Albania.

10 Judgment of ECHR, November 13, 2007. Application No. 38222/02, Ramadhi and Others v. Albania.
} 
enforceable right to have the land restored. That judgment was therefore not sufficient to generate a proprietary interest amounting to an "asset"'."11

Moreover, stated the Court, the belief that the latter administrative body's new decision, issued in compliance with formal requirements, would be in the applicants' favor cannot be regarded as a form of legitimate expectation for the purposes of Article 1 of Protocol No. 1. The Court recalls that there is a difference between a mere hope of restitution, however understandable that hope may be, and a legitimate expectation, which must be of a nature more concrete than a mere hope and be based on a legal provision or a legal act such as a judicial decision.

\section{Intervention of the State with Property Rights}

\subsection{Major Requirements: Lawfulness and Proportionality}

Although the state may interfere with property rights, there must always be adequate justification. The European Court of Human Rights will normally examine interference on the basis of the question whether such interference was justified. It will under normal circumstances pose three questions, which assist in determining whether the interference was justified: 1. Was it lawful? 2. Was it in the public interest? 3. Was it proportional? In other words: has the government, or the court for that matter, in its solution to the case, acted lawfully and found the right balance between the interests of the affected individuals and the interests of the state? In practice, lawfulness and proportionality are the major tests. The interference must always be based on the law. The state may furthermore not interfere disproportionately in the interests of an individual. Thus, a balance needs to be struck between the interests of the community and the fundamental rights of the individual. If that balance has not been struck, the property rights of an applicant have been violated. While the European Court often studies the third criteria of public interest, the test is virtually always complied with.

Both in cases of deprivation as well as in cases of control or limitation, the margin of appreciation of the state is very large with regard to property rights. The concept of margin of appreciation assumes that a government's discharge of its responsibilities in a democratic society is essentially a question of appreciating complex factors and balancing conflicting considerations of public and private interests. Certainly in the case of property rights the government may be assumed to possess a very wide margin of appreciation. The notion of 'public interest' is necessarily extensive. In particular, the decision to enact laws expropriating property will commonly involve consideration of political, economic and social issues.

\subsection{Interference leading to deprivation of property}

The right to property is protected against arbitrary or disproportionate forms of interference. Such interference can take the form of deprivation or the form of limitation of rights. It can even take a third form when the interference affects the enjoyment of the right to property. The following section focuses on deprivation.

In some of the cases against Albania, the Court has addressed the concept of deprivation of property rights (second rule) as a violation of Article 1 of Protocol No. 1.

Thus, in VRIONI and Others v. Albania the Court has held that the cancellation of a final decision that grants a person the title of ownership constitutes a deprivation of property rights within the meaning of Article 1 of Protocol No.1. The Court specifically stated that to the plaintiff ( VRIONI and others ) has been recognized the ownership title by a final court judgment and that such a decision can be regarded as a "possession" for purposes of Article 1 of Protocol No. 1, because "possession" can be "existing possesions " or assets, including, in certain defined situations claims. As a result of the supervisory review proceedings, the cancellation of a binding decision, has violated the trust of the plaintiff to a binding judicial decision and deprived them of the opportunity to enforce their ownership title. In these circumstances, we have a deprivation of property rights within the meaning of Article 1 of Protocol No. $1^{12}$.

While, in the case Marini v Albania the Court noted that in the present case the applicant held a $50 \%$ stake in the Marini-Albplastik company. Following repeated actions by the State which ran counter to the terms of the agreement, the applicant had no decision-making power in the company. Consequently, there were changes in the powers the applicant exercised as a shareholder, that is to say in his ability to run the company, control its assets and receive its profits. In the light of the circumstances of the case and having regard to the special nature of the applicant's possessions, the Court

\footnotetext{
11 Judgment of ECHR, October 23, 2007. Application No. 10508/02, Gjonbocari and Others v.Albania

12 Judgment of ECHR, March 24, 2009. Aplication No. 2141/03, Vrioni and Others v. Albania.
} 
does not consider that the interferences can be classified in any specific category within Article 1 of Protocol No. 1, because in this case there was no direct deprivation of the right to property and interference by local authorities comparable to such deprivation, but only a violation of the right to peaceful enjoyment of property.

\subsection{Interference leading to limitation in the Enjoyment of Property}

The state may limit the enjoyment of property in public interest. There are almost innumerable forms of limitation of property rights. For instance, the state may, for planning reasons or for safety reasons, limit the freedom to build houses and impose speed limits on driving.

In most cases against Albania, the Court found that there had been interferences by the Albanian State that led to the limitation of quiet enjoyment of property rights in the sense of Article 1 of Protocol No. 1.

In Ramadhi and Others $v$. Albania the Court observed that the interference with the applicants' right to the enjoyment of their possessions stems from the continuing failure to pay them the compensation stemming from the Commission's decisions and to return to the first three applicants the property of which they had been recognized as the owners by the Land Commission. It reiterates that the non-enforcement of a decision recognizing title to property constitutes interference which falls to be examined under the first sentence of the first paragraph of Article 1 of Protocol No. 1, which lays down the principle of peaceful enjoyment of property in general terms. In the assessment, whether a fair balance was struck between the demands of the general interest of the community and the requirements of the protection of the individual's fundamental rights, the Court reiterates that States have a wide margin of appreciation to determine what is in the public interest, especially where compensation for nationalization or expropriation is concerned, as the national legislature has a wide discretion in implementing social and economic policies. However, that margin of appreciation is not unlimited and its exercise is subject to review by the Convention institutions. The failure of the domestic authorities over so many years to determine the final amount of the compensation due or to return to the first three applicants the plot of land now allocated to third parties has resulted in an interference with the applicants' property rights, which in the Court's view is such as to have placed an excessive burden on them. In the light of all the circumstances, the Court considered that there has therefore been a violation of Article 1 of Protocol No. 1 as regards all the applicants in respect of the issue of compensation and as regards the first three applicants in respect of the issue of restitution 13

The same position the Court has held even in cases Nuri v.Albania, Hamzarja v. Albania and Driza v. Albania, arguing that recognition of the right to compensation by a final decision of the Commission on Restitution and Compensation of Property and then non-enforcement of this decision by not defining or not giving the amount of compensation for a long period by the competent authorities constitutes a violation of quiet enjoyment of the right to property.

In Driza v. Albania, the Court considered that, by not setting up the appropriate bodies to deal with the compensation issues or adopting site plans for the valuation of the properties, the Government failed to establish an adequate procedure in relation to the compensation claims. Moreover, it is unlikely that the Government will put in place such a system imminently or within a span of time sufficiently short to enable the settlement of the dispute related to the determination of the applicants' rights and for these reasons the Court found that the applicant was denied an effective remedy for the alleged breach of his rights under Article 1 of Protocol No $1^{14}$.

In Marini v. Albania the Court noted that the State failed to comply with its obligations under the joint-venture, putting him in the position of not being able to exercise effective control, in accordance with the law, over MariniAlbplastik's activities, with the result that unlawful resolutions were adopted and the company was subsequently wound up. On this issue the Court has held that as regards the right guaranteed by Article 1 of Protocol No. 1, the state has the positive obligation to entail certain measures necessary to protect the right of property even in cases involving litigation between individuals or companies. It cannot simply remain passive and there is no room to distinguish between acts and omissions. In the present case, the reluctance of the executive authorities and the bailiffs to honor the obligations entered into when the company was founded had a direct impact on the applicant's right to the peaceful enjoyment of his possessions and non enforcement of the decisions in the applicant's favor, the manner in which the proceedings were conducted, and the uncertainty in which the applicant was left, upset the "fair balance" that has to be struck between the demands of the public interest and the need to protect the applicant's right to the peaceful enjoyment of his possessions. Consequently, the State failed to comply with its obligation to secure the applicant's effective enjoyment of

\footnotetext{
${ }_{13}$ Judgment of ECHR, November 13, 2007. Aplication No. 38222/02, Ramadhi and Others v. Albania.

14 Judgment of ECHR, November 13, 2007. Aplication No. 33771/02, Driza v. Albania.
} 
his right of property as guaranteed by Article 1 of Protocol No. 1.

On the other hand, in Nikolaus and Jurgen Treska v. Albania and Italy although the Court accept that the failure, over a period of several years to enforce the final decisions in the applicants' favor must have caused them a feeling of injustice and frustration, they have nevertheless not lost their claim against Albania. The Court noted that no domestic court has invalidated the applicants' title to the properties in issue. It observed in this connection that the national courts simply refused their request for enforcement measures on the ground that the respondent Albanian authorities lacked the capacity to take part in the proceedings, without examining - because of the legal nature of the action brought by the applicants in the national courts - the validity of the conflicting instruments of title or comparing them. Furthermore, the applicants' title to the property in question cannot expire with the passing of time; on the contrary, it can be converted into an entitlement to future compensation to be paid by the respondent Government pursuant to the domestic law in force relating to compensation for former owners. In those circumstances, stated the Court, the fact that the Albanian authorities omitted to take steps to restore possession of the property in issue to the applicants - on "public-interest" grounds directly linked to observance of the principle of State immunity, universally enshrined in both conventional and customary international law - did not upset the requisite balance between the protection of the individual right to the peaceful enjoyment of possessions and the requirements of the general interest ${ }^{15}$.

\section{The Past Violation and the Responsability of Albanian State}

One of the major difficulties in human rights law is the issue of how to deal with past violations. Can human rights law solve all such problems of the past? The answer is clearly no; in most cases because such massive or systematic violations often took place before accession of the state concerned to the human rights treaties. Problems of the past receive special attention in the case of the right to property. No issue can occupy minds so much as the loss of land in the distant past. One cannot overlook, when discussing injustice, the injustices of the past. In Europe the past has enormous relevance due to the many wars and their aftermath. World War II is an example of the magnitude of the problems of land and other properties. Before and during the war land and properties of tens of millions of people were destroyed or arbitrarily seized or confiscated

Given that most of the cases against Albania related to expropriation, nationalization or confiscation of the Albanian state during the communist period, another issue that deserves attention is the one that has to do with the violations committed by the Albanian state in the past (before the ratification of the ECHR) and its responsibility for these violations.

In Beshiri v. Albania the Court affirmed one of the above mentioned general principles that Article 1 of Protocol No. 1 cannot be interpreted as imposing any general obligation on the Contracting States to return property which was transferred to them before they ratified the Convention. Nor does Article 1 of Protocol No. 1 impose any restrictions on the Contracting States' freedom to determine the scope of property restitution and to choose the conditions under which they agree to restore property rights of former owners. In particular, the Contracting States enjoy a wide margin of appreciation with regard to the exclusion of certain categories of former owners from such entitlement. Where categories of owners are excluded in this way, their claims for restitution cannot provide the basis for a "legitimate expectation" attracting the protection of Article 1 of Protocol No. 1. On the other hand, once a Contracting State, having ratified the Convention including Protocol No. 1, enacts legislation providing for the full or partial restoration of property confiscated under a previous regime, such legislation may be regarded as generating a new property right protected by Article 1 of Protocol No. 1 for persons satisfying the requirements for entitlement. The same may apply in respect of arrangements for restitution or compensation established under pre-ratification legislation, if such legislation remained in force after the Contracting State's ratification of Protocol No. 1

While with regard to this case, the Court considered that the problems involved in the applicants' case are part of the process of transition from the former communist legal order and its property regime to one compatible with the rule of law and the market economy. Such a process, in the very nature of things, is fraught with difficulties. The Court has held in this connection that the Convention cannot be interpreted as imposing any general obligation on the Contracting States to restore property which was transferred to them before they had ratified the Convention. Nor is there any general obligation under the Convention to establish legal procedures in which restitution of property may be sought. However, once a Contracting State decides to establish legal procedures of such a kind, it cannot be exempted from the obligation to honour all relevant guarantees provided for by the Convention, in particular in Article $6 \S 1$.

In Nikolaus and Jurgen Treska v. Albania and Italy, as to the applicants' argument that the transfer to the Italian

15 Judgment of ECHR, June 29, 2006. Aplication No. 26937/04, Nikolaus dhe Jurgen Treska v. Albania and Italy. 
authorities of the property belonging to their father had been unlawful, the Court noted that the transaction between the Albanian Government and the Italian Government, which the applicants considered to have been null and void, took place in 1991, in other words before 2 October 1996, the date on which Albania ratified the Convention and Protocol No. 1. It follows that this part of the complaint is incompatible ratione temporis with the provisions of the Convention and must be rejected in accordance with Article $35 \S \S 3$ and 4 of the Convention.

\section{Concluding Remarks}

As analyzed above in this paper, the complexity in the nomination and therefore in the handling of property rights as from the perspective of domestic law but also from the principles of the Europian Convention and the ECHR leaves us to understand the difficulty of existence of property, to the state's unwillingness to implement constitutional and legal guarantees (domestic and international ) in property protection, the creation of state bureaucracies with many links and many times in vain, to be exhausted to ensure minimum rights to property and as a result for the instability that creates the birth, change and termination of the legal relationship of property. This situation, so complex and phenomenal in our society, creates greater legal uncertainty in having and especially defending private property being considered as the most vulnerable in comparison to public property. Ownership therefore remains one of the most difficult relationships to be experienced by society for reasons mentioned above, to be considered as one of the most vulnerable relations from the state. With all the problems that carries the property relationship, especially in Albanian society, we can say that the property is the foundation of a free economic order without which we can not stand and understand a legal and social order. The only legal solution that remains to be suggested or recommended to persons which are subject of property relations as concerning the protection of their property rights if they do not find solutions through exhaustion of domestic remedies is the direction to the legal path guaranteed by the Europian Convention and recognized by the Albanian state, not because it gives guarantees for the acquisition of the right of ownership (if denied by the internal state court decision ) but beacuase a subject is treated differently in the conception of his rights or in its enjoyment.

The relevance of protection of property rights for a life in dignity has amply been demonstrated by the cases discussed in this chapter. The protection of property is essential for individuals to live in security. The protection raises, however, numerous issues related to terminology and concepts. It also raises questions related to different forms of security such as social security.

It is expected that the large stream of property cases before the European Court will continue. Major issues that are likely to be raised are the following:

- the meaning of property, notably in relation to social security issues;

- the discussion as to what constitutes an expropriation or deprivation;

- the concept of limitations or control or encroachment;

- the definition of compensation and the question how to deal with violations in the distant past; and

- the protection of common property or property held by a number of persons collectively.

\section{References}

Dollani Nada, LL.M, Nuni Ardian, Assoc.Prof.PhD (2006). The right to property under the Europian Convention on Human Rights. Legal Studies Journal Vol. 1. Tirana.

Judgment of ECHR, August 22, 2006. Aplication No. 7352/03, Beshiri and Others v. Albania.

Judgment of ECHR, June 29, 2006. Aplication No. 26937/04, Nikolaus dhe Jurgen Treska v. Albania and Italy.

Judgment of ECHR, December 18, 2007. Aplication No. 3738/02, Marini v. Albania.

Judgment of ECHR, November 13, 2007. Aplication No. 38222/02, Ramadhi and Others v. Albania.

Judgment of ECHR, November 13, 2007. Aplication No. 33771/02, Driza v. Albania.

Judgment of ECHR, February 3, 2009. Aplication No. 45264/04, Hamzaraj v. Albania.

Judgment of ECHR, February 3, 2009. Aplication No. 12306/04, Nuri v. Albania.

Judgment of ECHR, March 24, 2009. Aplication No. 2141/03, Vrioni and Others v. Albania.

Judgment of ECHR, October 23, 2007. Application No. 10508/02, Gjonbocari and Others v.Albania

Europian Convention on Human Rights (1999). Council of Europe in Tirana. 